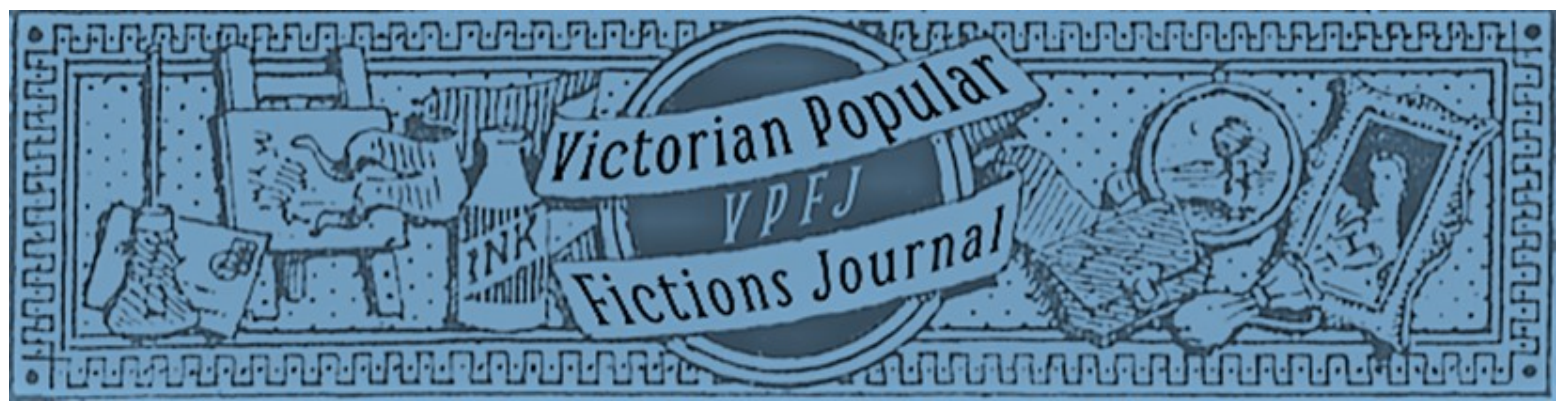

\title{
Women and Children First: Appropriated Fiction in the Ten Hours' Advocate
}

\section{Rob Breton}

\begin{abstract}
This article examines interclass strategies to bring about reform in mid-nineteenth century England. It specifically explores the way the Ten Hours' Advocate, a paper written for the working classes, looked to present itself as a middle-class periodical in order to further the argument for factory reform. In reproducing fiction filched from middle-class periodicals, the Advocate performed its argument for the Factory Bill: that the Bill would ease social tensions, dissipate the Chartist or radical threat, and ensure a "return" to traditional gender roles. The appropriated fiction is mild, rather bland; the non-fictional argument for reform is direct and unapologetic. That the Advocate was opportunistic in the way it made the case for reform is an example of the advantages provided to reformers by the absence of strict copyright laws and by Victorian periodical culture in general. But it also contextualises the debate over the family-wage argument and the working-class role in hardening the Victorian sexual division of labour.
\end{abstract}

\section{Keywords}

Victorian periodical culture; Ten Hours' Advocate, factory reform; family wage; gender roles; radicalism; Chartism

Date of Acceptance: 8 December 2021

Date of Publication: 17 December 2021

Double Blind Peer Reviewed

\section{Recommended Citation:}

Breton, Rob. 2021. "Women and Children First: Appropriated Fiction in the Ten Hours' Advocate." Victorian Popular Fictions, 3.2 (Autumn): 63-75. ISSN: 2632-4253 (online) DOI: https://doi.org/10.46911/FSMI1264

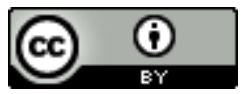

This work is licensed under a Creative Commons Attribution 4.0 International License. 


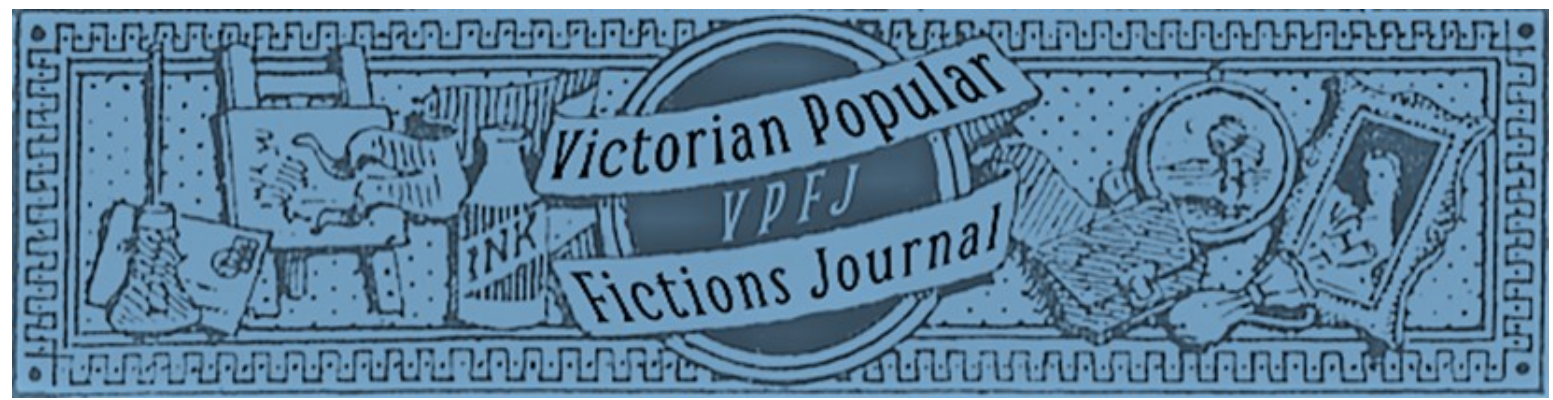

\section{Women and Children First: Appropriated Fiction in the Ten Hours' Advocate}

\section{Rob Breton}

\section{Introduction}

Fundamentally single-minded, the Ten Hours' Advocate and Journal of Literature and Art (26 September 1846 - 12 June 1847), "organ" or journal of the Lancashire Central Short-Time Committee, co-opted a great deal of fiction from a variety of contemporary periodicals to fill out its pages during its short run. It ostensibly had only one reason to exist. When the Ten-Hours' Act or Factory Bill was passed in June 1847, the paper immediately announced that it was folding and that it would issue only one more weekly number. None of the roughly thirty stories, serialised excerpts from long novels to short stand-alone fiction, were original to the paper, and its plentiful page-filling miscellany was also reproduced from other sources, often, as with the stories, having been first published only weeks before being copied into the Advocate. The supplemental material demonstrates patterns of selection and appropriation coordinated to reinforce the argument for reform. Against the spectre of working-class radicalism and violence, it describes and prescribes working-class sobriety and forbearance, and promises limited change. Swiped from middle-class papers, stories where the vulnerable are rescued by beneficent benefactors, or where hardship and conflict is easily resolved, perform the Advocate's strategy for reform.

Looked at from a distance, only a very few of the adopted stories directly reflect the Advocate's program for factory reform, though there was plenty of fiction circulating at the time in the same papers that the Advocate took its material from that represent women and children degraded by factory work, causing familial ruin and so forth. Patrick Brantlinger is thinking of major writers such as Charles Dickens when he says that "With the return of more prosperous times after 1842 and with the partial victories of both the Anti-Corn Law League and the Ten Hours Movement, the fad for novels and poems about factory children disappeared" (1971: 279). In fact, the factory story was still easy to find in "family" and "improvement" periodicals such as Mary and William Howitt's People's Journal, and certainly the partial victories in factory reform prior to the paper's run were not considered sufficient by Philip Grant, editor of the Advocate. Though the one-penny, eight-page Advocate might have 
wanted to appeal to a readership beyond its announced and predictable audience, the working classes, or offer itself as a complete paper for that audience without the means to purchase all that it would wish to consume, the appropriated content at some level seems out of place and conspicuously innocuous, not just non-political but almost anti-political. Yet, the layers of conjectural manoeuvring behind the paper's schemes of appropriation, the use of middle-class voices, are imbued in and demonstrate popular strategies of persuasion and promotion, of soft selling, aimed at countering the image of the working classes that drew them as politically ambitious on the one hand or culturally deplorable on the other. Instead of treating the politics of the paper as an example of cultural hegemony, of the power of bourgeois domestic ideology to allocate gender roles, it is possible to read the Advocate as manipulating Victorian print culture to cultivate a politically advantageous position. Behind representations of eased social tensions, class harmony, or even the "subtext" of a working class eager for incorporation, is an attempt to win reform, setting the stage for further social change.

\section{Reform or Violence}

The point has been made repeatedly that "moral-force Chartism" used the cover of "physicalforce Chartism" to advance the fight for the Charter. John Walton, for example, says "Chartism's characteristic weapon was the petition to parliament, which it was hoped would carry the day by the sheer moral force of its constitutional logic, without needing to be backed by the physical force of an outraged people, although this was a threat which could be held in reserve and alluded to in more or less veiled ways by Chartist orators" (1999: 56). But promising peace and stability with reform and violence and revolt without it was a widespread tactic in the early and mid nineteenth century. Lord Ashley, afterwards Lord Shaftesbury, who introduced the Bill and ardently supported the paper, noted in his diary that advocating for the Bill "will do very much to win the hearts of the manufacturing people to Bishops and Lords ... it has already converted the hard mind of a Chartist Delegate" (quoted in Hodder, 1886: 369). Grant himself hints in his History of Factory Legislation that the argument to promote select working-class interests was best waged through appeals to middle-class power and thinly-veiled references to violence. Referencing the Bishop of Oxford's speech to parliament, he explains that advocates stressed how the Bill would ensure manufactures "security of property," a "superiority" that would face its greatest threat if in "conflict with the physical strength of the people" (Grant 1866: 134). The Bishop makes this case for averting violence:

Nothing was more dangerous than to refuse the petitions of a great body of the people, to leave their desires unsatisfied, to put them off with cold rejection, or even with needless delay ... The capitalists could exert a complete power over the working classes. How could these men resist? - only by combination.

Reform bills were commonly presented as a potential force of social stability, precluding strains of radicalism, muffling Chartists, especially in what Brian Maidment describes as "journals of popular progress," papers purportedly aimed at working-class readers but, as Maidment shows, with a patent "double-address" to both the working and middle classes (1984: 83, 88). These were often the same periodicals that the Advocate turned to for its supplemental materials, its fiction and miscellany. The image of placid, happy, reasonable, and forbearing working classes was set against the desperate need for reform - sanitary, tax, electoral, and so forth - qualifying the image by implying that good relations were contingent on reform. George 
Dawson in Howitt's Journal goes further by identifying the threat to the nation if the workingclasses were not appeased, stating that "Reform delayed is Revolution begun" (1848: 272).

Aligning itself with middle-class gentility, the Advocate carefully adopts a form of this strategy, balancing direct argument for the desperate need for reform in its original editorialising against the more equable appropriated content. The very platform of "improvement" conveys some intimation of what might happen if improvement is not achieved. In its indirect messaging on working-class culture, the Advocate offers to dissipate the idea of a working-class threat, acting as if the world were already a better, harmonious place and the people already cultivated or improved. Though declaring itself a working-class publication, it styles working-class culture as a mirror to middle-class culture, as if Sweeney Todd (1846-7) or the Mysteries of London (1844-8), "unrespectable" yet popular productions, were not concurrently available, and Chartism long gone. Selecting fiction from the most non-radical, unprovocative, and inoffensive writers available, the urgent need for reform is ostensibly undermined by constant pictures of social synchronisation or working-class "cheerfulness." However, siding with middle-class voices, absorbing and universalising them, even naturalising factory reform as a middle-class imperative, the Advocate can also be read as fully vested in exploiting the middle-class need to see itself as the official and universal culture.

\section{Significance of the Ten-Hours' Act}

Advocates for the Bill came from vastly different ideological groupings. Against the manufactures or capitalists were Chartists, Quakers, liberal reformers (including MPs), radical and regular conservatives, Lords, and ordinary working men and women. ${ }^{1}$ But agreement among groups that generally disagreed would only raise suspicions over each group's true objectives in having the Bill passed; Chartists and Tories, for example, had greatly different reasons for supporting the Bill. Grant thought it was to the advantage of the short-time movement to tread lightly: although the Bill was limited to reducing the working day for women and children only, much to the chagrin of Chartists, it had broad implications that made it potentially damaging to middle-class wealth. Thus Grant went out of his way to depoliticise the Advocate, later saying that he understood that the movement was opposed to "political economy" (1866: 126). This rhetoric downplayed how much the Bill signalled the redefining of liberalism to include regulation and limitations on laissez faire capitalism; even more dangerously, it signalled that reform could come "from below," that working people without the vote should have a say in Parliament.

The fiction that the paper adopted, however, suggesting that working-class preferences and tastes were the same as the ones "from above," had a soothing effect, promising that factory reform was the limit of its objectives, and circulating fictional worlds that insisted on the complementarity of working- and middle-class culture. For radicals and Chartists, factory reform was but one example of the need for structural change. Feargus O'Connor stated in Parliament, for example, that the Act should extend to adult male factory workers so as to "promote the amelioration of the people" (1850: 915). The Advocate's use of middle-class fiction ostensibly vows to re-contain the genie that the Bill could be used to set free. Against Chartist rhetoric that the factory system licensed "the right of capital to tyrannise over labour" ("Parliamentary Review" 1847: 4) was this promise to play nice, to isolate the Bill as much as possible from radicalism's attempt to address the root of social problems.

\footnotetext{
${ }^{1}$ Demonstrating the way women participated in the Ten Hours' Movement, Carol Morgan argues that women workers could be both for and against the Bill, with all of its assumptions and implications (1992 and 1996).
} 
Demonising factory owners and the "Factory System" had been and continued to be a rallying cry for working people. Grant, on the other hand, approvingly notes that most advocates for factory reform were not "political," pointing out that the movement itself shied away from identifying itself with politics, especially working-class politics: "Although Mr Pitkethley was of strong political opinions, taking an active part in the demand for the 'People's Charter,' he never mixed his politics with the Ten Hours' Movement" (1866: 122). Grant, who as the prolific Chartist writer of fiction and non-fiction Samuel Kydd tells us, had himself "suffered from the evils the supporters of factory regulation desired to remedy" (Kydd 1857: 246), saw the advantage of a non-confrontational approach. But the now socially-elevated Grant did not work alone. Looking specifically at the Lancashire Committee producing the Advocate, Sylvia Walby notes that "short-time committees were financed by the operatives" and that most "of the money was raised by the cotton spinners" (2007: 81), suggesting interclass complications were frequently at play within the Committee itself.

In other words, as Anna Clark notes while looking at the original editorial content of the paper, the Advocate was frequently "rhetorical," strategic or just careful, in its attempt to see the passing of the Bill. The significance of this careful rhetoric cannot be overstated because the Advocate is so frequently referenced as representing working-class attitudes towards women and work, and the notion that the roots of women's "inferior position to men in the labor market" can be found in the "sex-ordered division of labour" (Hartman 1976: 139, 137) specifically promoted by the paper. Heidi Hartman refers to the Advocate to argue "the role of men - ordinary men, men as men, men as workers - in maintaining women's inferiority in the labor market" (139). It is understandable that nearly all the conversation around the Advocate, as a declared working-class paper, has to do with its contribution to the gendering of labour that plays no small role in the exaggeration of nineteenth-century gender roles. That the Advocate declared a desire to gender work, to reduce if not eliminate a woman's chance of getting paid work, can hardly be debated. Hartman quotes the paper:

It is needless for us to say, that all attempts to improve the morals and physical condition of female factory workers will be abortive, unless their hours are materially reduced. Indeed we may go so far as to say, that married females would be much better occupied in performing the domestic duties of the household, than following the never-tiring motion of machinery. We therefore hope the day is not distant, when the husband will be able to provide for his wife and family, without sending the former to endure the drudgery of a cotton mill.

The rhetoric here is tricky. On the one hand, contemporary debate over whether the familywage argument - that paying men a higher wage would mean women did not have to work and the British (or American) family could return to normal - was rhetorical or if it was part of a deep-seated working-class conservatism is academic: rhetorical or not, female identity was being shaped as something inseparable from domesticity. Sally Alexander points out that "Whatever their intentions ... the factory reformers by submitting to the principle of the protection of women and every working-class custom, insofar as it refused an equal status to women within the class, placed women in a different relationship to the state than men. Women fell under the protection of their fathers, husbands or Parliament and were denied an independent political subjectivity" (1984: 146). On the other hand, at stake is the working-class role in separating work and home, its complicity in shaping domestic ideology and the cult of true womanhood. Though the nineteenth-century working class as a class is rarely assumed to be a determining force in official Victorian culture, its role in constituting or reconstituting the hard lines that separated Victorian men and women, public and private domains, assumptions of strong and weak, active and passive, has to be countenanced. 
Even critics who recognise that working-class patriarchalism was inherent tend to accept that it was overdetermined, from within and a by-product of a strategy to capitalise on an existing frame of reference. The emerging sensibility towards women's work might have been "rhetorical" or strategic, "a trope that performed specific political functions" as Clark says (1992: 63), and part of a firm ideological belief, existing as both a stratagem and an ideology. Nonetheless, the question surrounding ten hours' agitation, as Martha May puts it, has deep implications for feminist scholars: "Was the purpose of this [family] wage form working-class survival, female subordination, or still other factors that had to with capitalist control over the workplace?" (1982: 400). ${ }^{2}$ Despite huge differences between Chartists and factory reformers, both of these self-proclaimed representatives of working-class values come together over the gendering of labour, suggesting that more than just rhetoric was at play: in fact, men from all political stripes made use of the family-wage argument. ${ }^{3}$ But the way the Advocate impersonates middle-class taste, mimics or adopts middle-class culture as its own, or goes out of its way to resemble a non-working-class paper indicates that the gendering of work was at some level thought to be another way to patronise the middle classes and take advantage of cultural prejudices, even if either or both cultural improvement or gender differentiation were simultaneously and wholeheartedly part of its cause.

\section{Miscellany in the Advocate}

The periodical not only appeals to "traditional" female roles but to respectability in general: a snippet from Sir John Herschel informs the audience that reading "civilises the conduct of men, and suffers them not to remain barbarous" (1847: 200). The paper recognises from the outset a responsibility to promote "such knowledge and art" as to teach all working people useful activities during their newly found hours of leisure, and that they will combine "instruction with amusement" in order to be of "good account" to the operative classes kicking up their feet, though of course those hours had not yet been won ("To Our Readers" 1846: 1). "Instruction and amusement" is the language of many popular and Chartist periodicals vying for working-class readers, but also ubiquitous in middle-class papers. Much like the many interventionist, reformist, and usually family-friendly papers emerging in the late stages of Chartism, such as Howitt's Journal or John Cassell's Working Man's Friend, and Family Instructor, the Advocate directs itself to both its declared audience, working people, and to the middle classes, as if the latter were hovering over the paper and surveying its content. The miscellany especially reinforces the promise of "improvement." Readers are told to speak gently to their sons and daughters and that such a compassionate tone will regulate the child's behaviour more than harsh punishment. The advice is attributed the Christian Register. A good number of inserts appear to be modelled on useful-knowledge journals such as Charles Knight's Penny Magazine, periodicals that attempted to redirect working-class grievances

\footnotetext{
${ }^{2}$ Speaking on the various groups that took part in the "debate on women and work which raged in Britain in the second quarter of the 19th century," Marianna Valverde notes that, "it is crucial to be aware of the differences among these groups' agendas. For example, the campaign to restrict the hours and occupations of women and children has often been seen either as a glorious step in the forward march of labour (this is the Whig/Labour interpretation) or as a cross-class male conspiracy to limit women's choices and diminish their earning power: a more concrete analysis reveals the 'Short-Time' campaign as the coming together of very disparate groups, and thus as not reducible to a single meaning" (619). Robert Gray speaks of the "variable and contested meanings of the factory question and the construction of these meanings in specific contexts" (1996: 9).

${ }^{3}$ As May notes, "The role of the dependent family in the ideology of the family wage gave this wage demand added acceptability outside the working class" (1988: 403).
} 
towards "mental cultivation" and culture. We get, for example, an article on the "Manners and Customs of Ethiopia" (1847: 228) from the Imperial Magazine. Admitting working-class roughness and the need for improvement from middle-class sources, the Advocate blames overwork, making itself an example of the innocuous activities working people would follow with reduced work hours.

As might be expected, some of the added material also directly matches the paper's agenda of naturalising women as fully content in the home. We get the frequently reproduced "Parallel of the Sexes":

Man is strong, woman is beautiful; man is daring and confident, woman is diffident and unassuming; man is great in action, woman in suffering; man shines abroad, woman at home; man talks to convince, woman to persuade and please; man has a rugged heart, woman has a soft and tender one; man prevents misery, woman relieves it; man has science, woman taste; man has judgement, woman sensibility.

(1847: 216)

This had appeared as early as 1811 in The Freemason's Magazine but had been widely reproduced in numerous papers before being repackaged by the Advocate. ${ }^{4}$ The paper also includes "How to Choose a Wife" from James Fordyce's Sermons to Young Women ([1766] 1846: 32). This line of material, at least, demonstrates that the editors and compilers were not simply selecting material because it was within reach. Numerous snippets on "Woman" taken from papers such as the New Monthly Magazine make it clear to audiences that working women would model themselves on middle-class ideals if given the means. In between "Addresses" to factory owners, the Advocate includes advice on knitting and cooking, how to crochet or bake mutton and not the simple sewing and cooking working-class women would more likely need to know, though still patently gendered columns that act both as a guide to reading the Advocate as a gendered family magazine (some material for women, some for men, and some for children) and as a signal that factory reform was a sociallyconservative, contained, self-limiting measure. The Bill had not passed at this point; presumably the working women being addressed did not have time to knit a "Fine Berlin Wool doubled" sofa cushion (1847: 214). The columns, borrowed from Mrs William Savage's Winchester Fancy Needlework Instructor, and Manual of Knitting and Crochet (1846) or Mrs Hannah Glasse's Complete Art of Cookery (1843), act to assure that the Bill would strengthen the seriousness and sanctity of the British family, re-entrenching naturalised gender roles and eliding class differences.

Again, whether this was entirely a ploy to advance the Bill or part of a deep-rooted belief in restricting gender roles is an impossible question, for it may have been both, just as it may have been written to both direct working people and appease an imagined middle-class audience. The miscellany itself could be double-voiced, used to gently reinforce the agenda of the paper, carrying a politicised message to working-class readers, while appealing to what middle-class reformers might want to hear. An article called "Good Advice" calls for young unmarried men to save money because it will be more difficult to do so after they marry, but also because if they become desperate for drink or to gamble, they will accept low wages, thereby driving down wages for all (1847: 270). It also recommends workers defer gratification,

\footnotetext{
${ }^{4}$ Though not a fool-proof method for finding earlier sources of reproduced but unattributed materials, standard search-engine searches of unadulterated passages in quotation marks will usually produce results. Full-text searches are often less effective than a single-sentence search. The "Scissors and Paste Project" (http://www.scissorsandpaste.net) tracks reprinting and reuse in newspapers from the Anglophone world between 1783 to 1914. See Beals (2017) for a description of the project.
} 
marry and start a family, as opposed to leading the bachelor's life of dissipation; but the argument for prudence gets a firmly union twist when the paper tells readers to keep "a little stock in hand" so that they can afford to withhold labour when necessary (270). The Advocate carries a great deal of advice specifically for men, imaging working-class men in the shape of middle-class stereotypes. Though the Factory Bill was to reduce hours for women and children, the Advocate underlines the need for the moral improvement of men, how they would be improved by fewer work hours. It exposes a degree of working-class radicalism by consistently writing as if the Bill in front of Parliament would change the hours that a man would work, allowing men more time for improvement. "Husbands and Wives," for example, originally from Chambers Edinburgh Journal, calls for more conduct manuals for men, seeing that there are so many for women and "The man is to blame in nine cases out of ten where an alliance proves unhappy" (1847: 276). The article is about the need for better "domestic behaviour" among men, arguing that men in particular would benefit from the "improvement" that a shorter work week guarantees. Insofar as it mimics middle-class periodicals reaching out to an imagined working-class audience with a message of education and personal moral reform, it might be understood as an "attempt to win consent to or compliance with dominant ideology" (1981: 31), as Tony Bennet has said. But to whatever extent hegemony was at play, the Advocate may be better seen as gaming the system, using the dominant ideology to push for a continuous stream of progressive reforms.

\section{Fiction in the Advocate}

If the miscellany slips in an argument for wider reform beyond short time, the fiction in the Advocate mostly depoliticises such content, providing an image of calm and defining a working-class audience uninterested in anything but the kind of moral improvement that would be amenable to the middle classes. Most of the paper is filled with reports on meetings, how delegates from different regions voted on new measures, and so forth. The fiction was the paper's primary means to disentangle itself from any association to radicalism and to isolate it from any accusation that the movement was fundamentally oppositional. The issues are stuffed with stories of natural goodness where conflict is easily overcome by a general desire from every branch of society to further mutual interests. In contrast to the fiction in Chartist papers, for example, the stories avoid representing overwhelming social problems. Some are conduct narratives and can be seen as corresponding to the paper's agenda to improve readers. But for the most part the stories are remarkably vacuous, generally dull but symbolic, taken from and easily transferable into countless other papers, and that was the point. The first story is identified as "A Tale of our Own Times" but unattributed. It is an extract from Catherine Sedgwick's Clarence; or, A Tale of our Own Times (1830), a novel that is set in New York, so the representation of poverty, garret houses and wicked landladies, would be geographically displaced for the Advocate's readers. The novel features sentiments that support the argument of the paper, namely the value of childhood: "The love of childhood is a tie to our species that even misanthropy cannot dissolve" ([Sedgwick] [1830] 1846: 6). But there is as much or more in the novel that distracts from the Advocate's argument than what could be interpreted to support it: with its representations of misers and selfishness, it also, very sentimentally, demonstrates that "mediocrity of fortune is most favourable to virtue" ([Sedgwick] [1830] 1846: 31). It is possible that the novel was scooped up because of a simple need for content and it was convenient to do so. The Advocate breaks up the story eliminating chapter breaks for example - in ways that indicate the main interest in reproducing the story was to reach the bottom of the page. Nineteenth-century typesetters and compositors often acted like copy-editors, making changes to the text for a variety of reasons. 
But the way the paper scraps the majority of the original, abruptly and unceremoniously stopping at about its midway point, then tacking on a summarising conclusion, suggests Grant had thought that at this random point the story had served its function of guiding or demonstrating his readers' interest in disinterested reading.

A number of stories seem selected to please middle-class readers who may have been concerned that factory reform was a cover for either working-class laziness or ambition. A brief story titled "Hard Diet" (1846: 32) reports on an indentured servant's complaint about having to eat the same meal day in and out, leading to him running away (and why he is up in front of a recorder, or judge). The recorder tells the master to get a new servant. It is difficult to read the moral here: the boy comes off as bratty and ungrateful. Taken from the Boston Post Newspaper but also reproduced in Glasgow Herald, it replicates arguments coming from the employer class. If that story demonstrates a need for a stern lesson in authority, others seem to have been selected to demonstrate a working-class attraction to cheerfulness, or that it was repulsed by "morbidity," a term used at the time to describe popular, non-improving literature. But most of the stories simply show just how easily conflict can be resolved, usually by good fortune, a higher-up helping out and guiding the victim of bad luck until the happy ending is reached. "The Returned Slave" (1846: 20-1), unattributed but from Chambers, includes a generous nobleman who acts as a deus ex machina, providing money so a worthy son can get his father out of slavery. "Will Block - A True Tale" (1847: 157-9), also from Chambers, is a fallen-woman story that ends happily, the woman here being taken care of by Will Block, who reunites her with her lover. "The Kelp Gatherer" (1847: 150-2), republished from the Cabinet Album, sees a son go off to make his fortune, promising to return to his mother. He does, but she has become blind until a doctor fixes her sight and everyone is happy. It goes on and on. Three stories from "Past and Present Times, by a Lady" "The Cavern of Caversham" (1847: 221-3, 229-30), "Christina of Wolfenbuttel" (1847: 23840), and "The Italian Bandit" (1847: 294-5) - are historical romances where conflict somehow leads straight to marriage and a happy ever-after. ${ }^{5}$ That the author of three of these uplifting stories is identified as "a Lady" can be read as to suggest that women's interest should be in overcoming the political, ${ }^{6}$ though again they hardly speak to the difficulties of working women.

Not all the stories reproduced in the Advocate end happily, and the paper might have been imagining a rough gendering of stories where the ones for women do and the ones that were thought to be for male readers vary. Anecdotal narratives about the importance of staying on the straight and narrow, clearly directed at improving male behaviour, are less likely to end up happily. ${ }^{7}$ Still, the happy endings, passive protagonists, and easy narrative resolutions are overwhelming. "The Lamenter: An Irish Story" (1847: 247-8), from Chambers, tells of an Irish wedding where Judith wants her lover to marry her so she arranges to marry the lamenter, a lame man. Her true lover finally marries her and the lamenter also lives happily ever after.

\footnotetext{
${ }^{5}$ A number of American adventure stories about the wild west such as "A Perilous Situation" (1847: 189-91) from Auduban's Ornithological Biography essentially follow this same pattern where protagonists are saved by serendipity at the last moment.

${ }^{6}$ A fourth story from "Past and Present Times, by a Lady," "Margaret Neville" (1847: 246-7), is about a seduced young woman who commits suicide. But even here, her "destroyer" eventually dies, ostensibly producing the moral that Providence is to judge.

7 "Amelia Mildmay" (1847: 165-7), from The Selector, or Cornish Magazine, has the heroine Amelia saved by the wealthy Alfred from ruffians. Alfred falls in love with Amelia and secretly proposes to her: his family would not approve. But he begins to spend time in London society, forgetting Amelia. He marries Louisa; Amelia dies in grief after confronting him and he dies soon after that.
} 
Again from Chambers, "A Tale of the Forty-Five" (1846), a historical romance set in eighteenth-century Edinburgh, is primarily "a love tale" version of the story of William Douglas, a highlander rebel, who gives up the cause of rebellion to be a happy, respectable citizen, married to the girl of his dreams.

It is far from unusual for a Victorian story to end happily, though Chartist fiction generally does not. However, these romances and the American wild west stories in the paper do not sit comfortably besides the high seriousness of its explicit goal to improve and instruct. As with so many other reform journals from the era, the Advocate tells readers to avoid cheap, popular romances. The editors disparage the theatre because popular or working-class productions merely have the same function as the alehouse, "to shake off the lethargy produced by toil," not to improve the moral character of the audience. They state, "by lessening the hours of work, you may lessen the disposition to attend theatres." The editors are also against "romances and novels in Mechanics Institutions, which every librarian well knows constitute the bulk of the works that are perused" ("The Evils of Long Hours" 1847: 191). Yet the paper then reproduces dreamy romances. "A Romance in Stage Life" even tempts readers by saying that it, "for stirring interest and romantic story, far outdoes all such dramatic fictions as The Wife of Two Husbands, The Fatal Marriage, or those numerous misadventures and mishaps in connection with love, marriage, and triumphant virtue ..." (1847: 208). The Advocate's claim to instruction and moral seriousness while reproducing sentiment, action, and romance was far from unusual among cheap periodicals said to be for the working classes - even Newgate Calendars averred to be instructional. But by sourcing the "popular" content from contemporary middle-class papers it pre-emptily diverts criticism that it was straying from the principles of respectability.

Perhaps the most topical of all the stories in the Advocate is "The Factory Beggar Girl: A True Story" ([Aiken] 1847: 206-08) taken from John Critchley Prince's Quarterly Magazine where it is attributed to "Omega." The original story is from Oddfellows Magazine where the author, William Aiken, is identified. In the story, a woman who has lost her hand to a machine is reduced to beggary but, when assisted by a gentleman, she lives happily ever after. The story demonstrates, as Trygve R. Tholfsen says, that "Aiken shared the mid-Victorian assumption that the social system was fundamentally sound, and required only more virtuous and understanding behaviour on the part of all classes" (1977: 259). It ends with a direct comment to readers:

This is another proof of the necessity of gentlemen being careful to whom they entrust their power [overseers], as that power is, in too many instances abused. It also proves the necessity of the working classes appealing to the fountain head, in a proper and decorous strain, when they find any subordinate acting unjustly, and usurping powers that belong not to him.

([Aiken] 1847: 208)

At best a soft criticism of the factory system and certainly not resembling the many stories about factory abuse in Chartist or even the more radical middle-class papers that the Advocate perused for material, the story acts as a signal and sign that factory reform was a measured response to a small group of employers. At other points, the paper includes direct commentaries on the desperate need for reform, but not in the fiction it selected for its cultural image. A short excerpt taken from Douglas Jerrold's Shilling Magazine on "Children's Deaths in Manchester," about the disproportionately high infant mortality rate caused by mothers giving their children opium to quiet them down when they were at the factory (1846: 64), pulls no punches. 
But the Advocate's choice to reproduce "The Factory Beggar Girl: A True Story" and not Jerrold's own "The Factory Child" (1838), which was reproduced repeatedly in Chartist periodicals, ${ }^{8}$ suggests a deliberate strategy to announce allegiance with the middle classes or middle-class periodicals through the promise of class harmony.

\section{The End of the Advocate}

Something happens with the appropriated fiction, however, very late in the Advocate's run. The exact week that the Factory Bill passed and the Advocate announced it was shutting down its operations after one more issue, Grant reproduced arguably the most radical story he ever ran, "The Mechanic's Wife" (1847: 292-4) by Mary Leman Gillies and written for Mary and William Howitts' People's Journal. The story was picked up by a number of other publications, but it reads uniquely in the Advocate. This is only the second time the Advocate turned to the Howitts for material and this is the first story it reproduced from the paper. Though the Howitts' papers were firmly "improvement" oriented, their radical credentials are not disputed in part because they were much more concerned with reproducing genuine working-class concerns and voices than the papers that the Advocate had turned to before the passing of the Bill. ${ }^{9}$ In the story, the husband is an ideal working-class man, cultivating his mind; but the wife, Susan, is left without the chance to improve herself intellectually, though she is morally good. The point is made directly many times: "While he sought improvement for himself, it never occurred to him it was her equal right" (293); or "she uncomplainingly lived on without change, without stimulus, without excitement, shut up within the four walls of her humble home ... with her spirit full of capabilities unexplored and unexpanded" (293). Interestingly, the husband had been in need of a shorter workday as well; he had been injured and only because he cannot work can he "improve" himself. But she pines away and dies. The "march of the intellect" message is not surprising, but Susan is not a labourer; she is only a wife and mother, and the argument conveyed in the "how to cook mutton" sections of the paper is entirely destroyed. The husband is not exactly to blame - "He went to his club, the Mechanics' Institute ... he nobly determined to rescue himself from becoming the mere machine of toil, the drudge for so much "trash as can be grasped thus" (294). But he, like "society" in general, ignores her needs. The story suggests that the gendered division of labour that the paper so frequently insists upon in earlier issues, and that was implicit in the paper's explicit mission, is precisely to blame for Susan's death. It is likely this story that Anna Clark has in mind when she notes that

The attempts by Chartist women to broaden domesticity into a justification for political action or even a sense of themselves as reasoning beings faded as the Chartist public sphere was redefined as the domain of working men. The Ten Hours' Advocate, for instance, contained poignant tales of wives pining away in domestic monotony as their husbands neglected them for political meetings and mechanics' institutes.

(1992: 87)

\footnotetext{
${ }^{8}$ See the National (13 April 1839), Northern Star (same day, 13 April 1839), English Chartist Circular, Charter (3 March 1839), and Cleave's Gazette of Variety (16 March 1839).

9 "The People their own Patrons," for example, also by Mary Leman Gillies, announces and validates the language of "the People," arguing that the patronage system for artists is where "genius and skill became the drudges of luxury," and declaring that "Literature has long been utterly freed from a servile devotion to mere rank and wealth" (1847: 276). The article confirms the project of the Advocate, that literature will be one of the forces that saves working people from their "trammels," but in a way that accepts the intersection of class and literature. Written for the People's Journal, where it follows "Sonnet" by the Chartist poet Ebenezer Eliot, "The People their own Patrons" marks a notable turn of direction in the inclusion of a politicised women's voice.
} 
But Gillies, though radical at times, was not a Chartist, just as the Advocate was not Chartist. She could on occasion, depending on the situation or argument being made, herself argue that the best place for a married working-class woman was the home. Her essay / story "Associated Homes" is a near utopia, set in the future, 1857, where all the working people are sober, clean, and happy, and "No married women nor widows with children went out to work, but they might if they pleased take offices within the household, compatible with their duties as wives and mothers" (1847: 172). Despite what she says in "The Mechanic's Wife," Gillies too can use the image of happy domesticity for a specific purpose, in this later story arguing for a kind of Chartist-like land plan for working people. It is nonetheless important to note that, after the Bill was signed, the few stories selected by the Advocate are anything but the cheery distractions with happy resolutions that dominated the paper to this point. Only at this point in its run are struggling working people the main protagonists of the stories, and their stories do not end happily. A final story by Mrs W. N. Hodgson, again from People's Journal (slightly altered - Elizabeth Brown has become Elizabeth Green - though this is likely just a typesetting error) is hardly feminist or proto-feminist; Hodgson could be very conservative in her fiction. Women here are again in need of improvement, but improvement is limited to keeping a better home. "One Fault" (1847: 302-4) is a drunkard story where Joe marries a woman who cannot keep a good house - she does not clean it very well and cannot cook. He goes from being a respectable, worthy man to dying drunk, forcing her to beg. That the wife, unnamed, has never read or improved herself roughly matches the dominant message of the Advocate, that women need to be removed from the workplace so as to create better homes. But the wife's only workplace was her home, so the message in some ways is that domesticity is at best a partial, stopgap solution, if it is not something unnatural for some women. The terribly-depressing stories, that is, in the final two issues of the paper, announce that more, deeper reforms - now that Factory Reform had been accomplished - needed to be the next goal.

At the end of its run, the Advocate indicates that it seeks "something more," not unlike G. J. Harney's argument late in Chartism's run for the "Charter, and something more!" (1850: 351-2). Stating one last time that the purpose of the paper had been "the mental, moral, and religious improvement of the people," this well-used sentiment is followed by an original piece by Joseph Livesey on creating schools for child workers who now have two extra hours per day, for "Short-time Schools" (12 June 1847: 292). Livesey was a reformer and at this point had become a Chartist: the sudden politicisation or expansion of the paper's agenda argues that it had always had its sight on radicalising its platform or at least had always recognised the radical implications of its main argument but had kept that radicalism close to its chest so as to win the day one step at a time, women and children first. There are dangers in using the Advocate as an example of working-class attitudes on women's roles or on working-class culture. Though we should not assume that early Victorian working classes were merely imitating the official culture - the patriarchalism runs deep - the Advocate's posturing may begin to explain the compromising directions working-class movements took at the time, including Chartism's rejection of universal enfranchisement. Its method of advocating for reform, at the least, might be used as an example of the interclass games the Victorians were so good at. 


\section{Bibliography}

[Aiken, William] “The Factory Beggar Girl: A True Story." 1847. Ten Hours' Advocate (20 March): 206-8.

Alexander, Sally. 1984. "Women, Class and Sexual Differences in the 1830s and 1840s: Some Reflections on the Writing of a Feminist History." History Workshop, 17: 125-49. DOI: https://doi.org/10.1093/hwj/17.1.125

“Amelia Mildmay.” 1847. Ten Hours' Advocate (21 February): 165-7.

Beals, M. H. 2017. "Scissors and Paste: The Georgian Reprints, 1800-1837." Journal of Open Humanities Data, 3.1: 1-5. DOI: http://doi.org/10.5334/johd.8

Bennet, Tony. 1981. "Popular Culture: History and Theory." Popular Culture: Themes and Issues, 2: 29-32.

Brantlinger, Patrick. 1971. "Dickens and the Factories." Nineteenth-Century Fiction, 26.3: 270-85. DOI: https://doi.org/10.2307/2933206

“The Cavern of Caversham." 1847. Ten Hours' Advocate (3-10 April): 221-3, 229-30.

“Children's Deaths in Manchester." 1846. Ten Hours' Advocate (14 November): 64.

“Christina of Wolfenbuttel." 1847. Ten Hours' Advocate (17 April): 238-40.

Clark, Anna. 1992. "The Rhetoric of Chartist Domesticity: Gender, Language, and Class in the 1830s and 1840s." Journal of British Studies, 31.1: 62-88. DOI: https://doi.org/10.1086/385998

Dawson, George. 1848. "George Dawson on the Present Crisis." Howitt's Journal, 3 (22 April): 272.

“The Evils of Long Hours.” 1847. Ten Hours' Advocate (6 March): 191.

Fordyce, James. 1846. Sermons to Young Women. Ten Hours' Advocate (17 October): 32.

“Good Advice." 1847. Ten Hours' Advocate (15 May): 270.

Grant, Phillip. 1866. The History of Factory Legislation. Manchester: John Heywood.

Gillies, Mary Leman. 1847. “Associated Homes.” Howitt's Journal (27 March): 172.

[Gillies, Mary Leman] “The Mechanic's Wife.” 1847. Ten Hours' Advocate (5 June): 292-4.

[Gillies, Mary Leman] "The People their own Patrons." 1847. Ten Hours' Advocate (15 May): 276.

Gray, Robert. 1996. The Factory Question and Industrial England, 1830-1860. Cambridge: Cambridge University Press.

“Hard Diet." 1846. Ten Hours' Advocate (17 October): 32.

Harney, G. J. 1850. “The Charter, and Something More!” Democratic Review (February): 351-2.

Hartmann, Heidi. 1976. "Capitalism, Patriarchy, and Job Segregation by Sex.” Signs, 1.3: 137-69. DOI: https://doi.org/10.1086/493283

Herschel, Sir John. 1847. “Taste for Reading.” Ten Hours' Advocate (13 March): 200.

[Hodgson, W. N.] 1847. “One Fault.” Ten Hours' Advocate (12 June): 302-4.

Hodder, Edwin. 1886. The Life and Work of the Seventh Earl of Shaftesbury, K.G. Vol. 1. London: Cassell and Company, Ltd.

“Husbands and Wives." 1847. Ten Hours' Advocate (22 May): 276.

“The Italian Bandit." 1847. Ten Hours' Advocate (5 June): 294-5.

“The Kelp Gatherer.” 1847. Ten Hours' Advocate (30 January): 150-2.

“Knitting Sofa Cushion.” 1847. Ten Hours' Advocate (27 March): 214.

Kydd, Samuel. 1857. The History of the Factory Movement. Vol. 1. London: Simpkin, Marshall, and Co.

“The Lamenter: An Irish Story." 1847. Ten Hours' Advocate (24 April): 247-8.

Livesey, Joseph. 1847 “Short Time Schools.” Ten Hours' Advocate (12 June): 292. 
Maidment, Brian. 1984. "Magazines of Popular Progress \& the Artisans." Victorian Periodicals Review, 17.3: 83-94.

“Manners and Customs of Ethiopia." 1847. Ten Hours' Advocate (3 April): 228.

“Margaret Neville." 1847. Ten Hours' Advocate (24 April): 246-7.

May, Martha. 1982. "The Historical Problem of the Family Wage: The Ford Motor Company and the Five Dollar Day." Feminist Studies, 8.2: 399-424. DOI: https://doi.org/10.2307/3177569

Morgan, Carol E. 1996. "The Domestic Image and Factory Culture: The Cotton District in MidNineteenth-Century England." International Labor and Working-Class History, 49: 26-46. DOI: $\underline{\text { ttps://doi.org/10.1017/S0147547900001691 }}$

Morgan, Carol E. 1992. "Women, Work and Consciousness in the Mid-Nineteenth-Century English Cotton Industry." Social History, 17.1: 23-41. DOI: https://doi.org/10.1080/03071029208567821

O'Connor, Feargus. 1850. Hansard's Parliamentary Debates. $3^{\text {rd }}$ Series. Vol. CIX. London: Cornelius Buck.

"Parallel of the Sexes." 1847. Ten Hours' Advocate (27 March): 216.

"Parliamentary Review." 1847. Northern Star (13 February): 4.

“A Perilous Situation.” 1847. Ten Hours' Advocate (6 March): 189-91.

“The Returned Slave." 1846. Ten Hours' Advocate (10 October): 20-1.

“A Romance in Stage Life." 1847. Ten Hours' Advocate (20 March): 208.

[Sedgwick, Catherine] [1830] 1846. "A Tale of our Own Times.” Ten Hours' Advocate (26 September -5 December).

“A Tale of the Forty-Five." 1846. Ten Hours' Advocate (5-19 December).

“To Our Readers.” 1846. Ten Hours' Advocate (26 September): 1.

Trygve R. Tholfsen, 1977. Working-Class Radicalism in Mid-Victorian England. London: Routledge.

Valverde, Marianna. 1988. “'Giving the Female a Domestic Turn': The Social, Legal and Moral Regulation of Women's Work in British Cotton Mills, 1820-1850." Journal of Social History, 21.4: 619-34. DOI: https://doi.org/10.1353/jsh/21.4.619

Walby, Sylvia. 2007. Patriarchy at Work: Patriarchal and Capitalist Relations in Employment, 18001984. Cambridge: Polity Press.

Walton, John. 1999. Chartism. London and New York: Routledge.

“Will Block - A True Tale.” 1847. Ten Hours' Advocate (6 February): 157-9. 